\title{
Book review: Tomasz Grzegorz Grosse, Pokryzysowa Europa. Dylematy Unii Europejskiej (Post-crisis Europe. European Union's Dilemmas), Warsaw: The Polish Institute of International Affairs, 2018, pp. 313.
}

\author{
by Patryk Madej
}

In the last years in the Europe there is visible growth of Euroscepticism through European citizens. Nowadays reputation of the European Union is affected by high activity of right-wing political parties. The book of Tomasz Grzegorz Grosse is presenting a deep research on the current situation of the European Union and its position in the front of current challenges coming from the changes in the society. "Post-crisis Europe. Dilemmas of the European Union" is a publication that for sure can be seen as provocation, but from the other side - is giving possibility for every reader to understand the problems of the European Union from the other perspective.

Tomasz Grzegorz Grosse is a polish political scientist and sociologist, Professor at the University of Warsaw. His main areas of scientific interests are focused on the European Union, regional development, modern studies and management in public adminis- tration. Recent publications are related to the problems of the European Union, Brexit and internal relations of Member States.

The book consists of 313 pages divided into 9 chapters - each of them is titled with one word that describes the general idea of its content. Anyway, mentioned naming hinders general of the book review - titles are not giving any suggestion to the reader about the content, what force to read whole book page by page from the beginning, even if its structure allows to make it differently, about what I will mention later. The question here is what was the intention of the author - to ensure that readers respect the order of information proposed by him or to avoid potential misunderstandings that could appear during review of chapters without having relevant background from the previous one? No matter what the answer for this question is - every person that is interested in getting 
good overview of the current situation in the European Union with focus on current issues and potential impacts coming from the activity of Euroscepticists for sure must read this book.

One of the most interesting points underlined by the author already in the introduction to the book is explanation about the concept of "Post-crisis Europe". As it is explained, also in opinion of professor, even if mentioned phrase is popular in the literature and journalistic discourse, for sure is still imprecise and should not be seen as scientific term. The first thing that comes then in the mind of reader is - why this is then the title of the book? It is certain that this "conflict" of formulation was intentional. Anyway, this publication is presenting us the situation of the European Union during transitional period between two biggest problems of the European integration and moment of normalization of processes of the community.

The Introduction to the book that consists of five pages is mandatory part to read. It allows to understand the context of the current situation with presentation of reasons that brought European Union to the status quo. Explanation of all facts is done in very organized way, what allows every reader to know the basis of the main topic and, in later stages of reading, follow the cause-effect relationship explained in further chapters.

Every chapter of the book is divided in another sub-chapters the structure starts again with the introduction to the chapter, after which can be found substantive parts with relevant subtitles, in the end author adds conclusions coming from the presented analysis. It gives impression that book consists of small essays, what allows reader to read each chapter separately.

The first chapter of reviewed book is called "Sovereignty", consists of 22 pages and put the attention at the title aspect. In the introduction of it author underline nowadays importance of sovereignty and its continuous applicability in the time of the European integration. As he mentions, even if the assumptions of scientists and politicians were forcing the faith of disappearance of deep sense of nationality of citizens in case of growth of integration process, it did not only vanish, but also became stronger. The sub-chapters called "The approach of a school of international law", "The ap- 
proach of international relations" and "The approach of European studies" presents definitions of the "sovereignty" and its place in the European Union based on the facts coming from the Community political scene. In the conclusions author shows very accurate observations - one of the most interesting one is related to the position of smaller member states to their sovereignty during negotiations of economic benefits of their membership. The impression of scientists who is interested in the same area, as the book represents, can be that it does not present here anything new, anyway it concludes all the known facts in one place and creates easy thesis that precisely reflect the reality.

The second chapter "Democracy" consists of 34 pages. The main idea presented in this part of book is about the influence of the European integration on the democracy in the member states of the European Union. In the opinion of the author, the process had destructive impact on the democratic background and rules that were already existing in the countries. This argument is really provocative, especially in Poland from where the author comes. In the first sub- chapter scientist tries to answer the question "Is European integration a democratic process?", based on the above-mentioned opinion it is easy to guess his answer. Author presents structure and functionality of the European Union as imperfect and full of lack of democracy. The second subchapter "Does the integration limit the democracy in the member states?" in its biggest part shows the potential impact of the European Union on the social trust of the local politicians. "Is a "borrowing" of the democracy from the member states enough?" and "Illusion of parliamentary democracy in the European Union" are the tittles of next sub-chapter. They are for sure ones of the most provocative parts of the book, since they are a clear voice of Euroscepticism. Continuous chapters are continuing the main idea of the chapter and can make an impression that European Union is presented as a reason of political issues of all member states, anyway author does not make any judgement and continues the scientific analyse in the way, that the reader can conclude that the European Union and its activity is not as good as usually is perceived. 
Next chapter called "Political System", 30 pages, is related to the analysis of the system of the European Union with the context of federation and confederation applicability. In the later stage of study author is adding to the comparison authoritarian features, and also other regimes found by him as relevant to define the model that describes the nature of the European Union.

"Rebellion" chapter of 32 pages is a research of the condition of community. Author, step by step, is reviewing all factors that can push the European Union into disintegration. Therefore, book presents what is the impact of implementation of Euro and difficulties coming from that change and how much lack of democratic authority (as per the thesis presented in the previous chapters by author) are impacting the stability of European integration. In the results of research described in this chapter professor suggests, that potentiality of further disintegration is growing up due to the development of mentioned before factors.

Fifth chapter "Strategy", 34 pages, is result of another research of the author on the integration, in that case - the strategy of it. Chap- ter starts with mentioning about the "two-speed Europe" and focusing on it in the way to put the reader into negative feelings to the European Union. Additionally, in the first pages can be found strong phrase that German country is the leading one. Further studies on the Euro zone role, migration issue and defence policy are focusing on presenting Germany as country guilty of all the failures of the European Union in the aspects of integration. It starts to highlight the political goal of this book.

"Soldiarity" chapter, 22 pages, also starts with the argument that European Union, in that exact case European Commission, is in some way acting against the Member States. Author in the subchapters tries to find the references to the solidarity in the European Treaties and its presence in the discourse related to the migration issues. In the end, can be found an attempt to localize the titled value in the researched areas.

Next chapter "The Market", 42 pages, is a presentation of the most important changes that appeared on the European market, as the results of the crisis started in 2008. Subchapters describes also some of the decisions and actions taken 
by the authorities and their impact on the current importance of the European Union in the world.

Seventh chapter - "Disintegration", 24 pages, is not only another one part of the book, but in some way also conclusion of the previous ones in the front of the mentioned in the title issue. In the beginning author presents the Toynbee concept of the Universal State in order to compare it to the current status of the European Union. After this analyses as conclusion can be seen that the biggest dangers are going to happen. In the opinion of researcher, if no changes will apply to the current situation, mentioned by him results will follow.

Last chapter, "Forecast", and the shortest one (20 pages), is the attempt of author to answer the question what will happen with the European Union and its integrity. How much the suggestion closing this book is near to the reality? For sure it is one of the possibilities but basing this on the conclusions coming from the previous chapters and its analysis is as strong as deep is the trust in the foundations of the research.

Conclusion of the book, situated in the end, does not bring nothing more that was described in the chapters, what is the standard process. Anyway, it does not allow reader to understand fully problem of the book, it can be just treated as summary.

The book "Post-crisis Europe. Dilemmas of the European Union" for sure is a good example of scientific work of political scientist. Anyway, it does not mean that the material presented by him is a strong base for the conclusions coming from it. The title from the first moments suggests that the goal is to present the condition of the European Union after the crises that started in 2008. From the neutral point of view - the book would be based on the both, positive and negative, aspects of the community functionality. In this case, author focused his research mostly on the weak points of the institutions and bad opinions popularized during the propaganda of Euroscepticism. It is hardly impacting the final thesis - without objective attitude it is not possible to get objective conclusion. As written, the scientific process of analysis of the chosen materials is done with high level of quality.

The book for sure is mandatory position for every person that wants to understand the bad side 
of the European Union - the re- should not happen, since this book search here is a big value for the is a scientific work and should science. Anyway, whoever does make people know more. Therenot know the two sides of the same fore, this material is as beneficial coin, after reading this book can as rich is knowledge and objectivbe influenced by the content, what ity of reader. 